\title{
HISTORIFIKASI, ALINASI PADA TEATER EPIK BRECHT DAN SENI DRAMA TRADISI KETHOPRAK
}

\author{
Nuning Zaidah \\ Universitas PGRI Semarang \\ nuningzai@gmail.com
}

\begin{abstract}
Abstrak
Historifikasi, alinasi pada Teater Epik Bertolt Brecht mempunyai kemiripan dengan pertunjukan seni drama tradisi Kethoprak. Alinasi dalam naskah karya Brecht muncul dari rangkaian pemikirannya, yaitu HistorifikasiAlinasi-Epik. Historifikasi adalah usaha Brecht untuk menempatkan aktor seolaholah memainkan sebuah adegan sejarah. Alinasi adalah usaha untuk menggambarkan sebuah peristiwa ke dalam bentuk baru yang bertujuan untuk mencegah penonton menjadi katarsis, sedangkan Epik adalah diambil dari kata epos atau cerita kepahlawanan. Ketiga hal tersebut, alinasi menjadi unsur paling sering dibahas dalam konteks pembicaraan tentang teater Epik. Untuk mendapatkan alinasi, Brecht tidak menciptakan metode khusus pelatihan aktor dalam mencapainya, tetapi alinasi tersebut melekat dalam naskah yang ditulisnya. Alinasi didapatkan dari cara menganalisis struktur naskahnya. HistorifikasiAlinasi-Epik juga terdapat pada struktur naskah lakon-lakon pertunjukan seni drama tradisi Kethoprak berupa dialog, mood dan spectacle.
\end{abstract}

Kata kunci: historifikasi, alinasi, Teater Epik Brecht, Kethoprak.

\section{PENDAHULUAN}

Teater dan drama mempunyai arti sarupa tapi ungkapannya berbeda. Teater adalah proses pemilihan teks atau naskah, penafsiran, penggarapan, penyajian, pementasan, proses pemahaman, penikmatan dari publik atau audien (pembaca, pendengar, penonton, pengamat, kritikus atau peneliti) dan secara harfiah mempunyai arti tempat pertunjukan, sehingga teater mengandung arti pertunjukan. Drama merupakan karya sastra yang mempunyai arti berbuat, berlaku, berakting, bertindak, hingga drama memiliki sastra nyeni. Keduanya merupakan pertunjukan akting yang dilakukan diatas panggung dihadapan penonton, menggunakan naskah cerita dan dilakukan oleh banyak. Kata drama dan teater sama berasal dari bahasa Yunani Kuno, jika teater salah satu bentuk karya seni yang dipengaruhi oleh semangat jaman atau zeitgeist, terlihat pada karya-karya teater menurut jaman naskah tersebut diciptakan.

Sejalan dengan pemikiran di atas, bahawa seni teater dituntut berkembang sesuai jamannya. Akhir abad ke XIX muncul aliran realisme di dunia seni, aliran ini muncul karena ketidakpuasan terhadap aliran romantik yang dianggap sebagai utopia belaka (Sumardjo, 1986:79). Dalam dunia teater, muncul Henrik Ibsen sebagai salah satu tokoh kunci dan dianggap sebagai tonggak munculnya teater modern di dunia Barat. Meski merajai perkembangan teater sampai abad XIX usai, namun aliran ini tidak sepenuhnya diterima di abad XX. Hal ini ditandai 
bermunculnya aliran selain realisme pada awal abad XX, yaitu aliran simbolisme, ekspresionisme dan kemudian teater epik (Sumardjo, 1986: 82).

Perkembangan sesuai dengan jamannya juga terjadi pada teater tradisi Kethoprak, tetap memikat walau gampang sekarat di masyarakat. Kethoprak merupakan salah satu bentuk kesenian tradisional kerakyatan, yang tumbuh dan berkembang di kalangan masyarakat. Kethoprak mengalami periodesasi sejak lahir tahun 1887 sampai tahun 1925 di namakan kethoprak lesung, karena menggunakan alat penumbuk padi sebagai sumber suara iringannya, tahun 1926 sampai tahun 1927 Kethoprak mengalami perubahan baik iringan maupun pertunjukannya, maka pada tahun ini di sebut periode Kethoprak peralihan. Pada tahun 1928 Kethoprak mengalami perubahan total dengan gamelan sebagai iringan, periode ini di namakan periode gamelan (Suwardi Endraswara, 2011:178).

Teater Epik identik dengan Bertolt Brecht karena memang Brecht-lah yang mengembangkan teater Epik secara konsisten hingga menemukan bentuk yang mapan. Epik dipakai untuk menamai teater dalam pertunjukannya, Brecht menampilkan karyanya lebih mirip dengan cerita epos atau kepahlawanan dibanding teater konvensional yang berkembang dan diterima secara luas pada masa itu, dalam epos jalinan puisi dan prosa secara bebas silih berganti muncul. Seluruh cerita sengaja dilihat dari sudut pandang orang ketiga seperti dalang, tukang cerita atau narator. Si tukang cerita atau pembuat naskah secara bebas dapat mengubah waktu hanya dalam satu ucapan saja (Sumardjo, 1986: 99-100). Kecenderungan ini juga nampak pada bentuk-bentuk teater tradisi, seperti wayang orang, wayang kulit, wayang golek ataupun Kethoprak yang diperankan oleh masyarakat desa tanpa harus menggunakan teks. Kethoprak pada dasarnya merupakan cerita epos, yang menceritakan cerita-cerita kepahlawanan. Adapun untuk mencapai hasil seperti yang diharapkan, Brecht mempunyai satu komponen penting dalam pementasannya yang disebutnya sebagai Alinasi. Bagaimana persamaan historifikasi, alinasi pada teater epik Brecht dengan seni drama tradisi Kethoprak?

\section{Historifikasi-Alinasi-Epik}

Teater Epik Brecht tidak berdiri sendiri, melainkan merupakan sebuah rangkaian pemikiran yang menggambarkan realitas sosial dihadapi Brecht, yaitu: Historifikasi-Alinasi-Epik (Sumardjo, 1986: 99-100). Menurut Brecht gagasan tersebut menekankan pemahaman yang bersifat teoritis, pemikiran Brecht tentang historifikasi, alinasi dan epik diterapkannya pada naskah dan pemanggungan teaternya. Willet (1974:139-140) dalam Brecht on Theatre menjelaskan dua hal penting pendapat Brecht pertama bahwa historifikasi bersifat teknis. Kedua, historifikasi adalah usaha Brecht untuk menempatkan aktor seolah-olah memainkan sebuah adegan sejarah. Brecht menggunakan historifikasi diharapkan teater tidak memperlakukan subjeknya dengan maksud menyamakan dengan kehidupan sehari-hari dan diidentikan orang per orang, melainkan untuk dipahami sebagai gambaran manusia secara umum. Historifikasi akan terlihat jelas bila mengambil cerita dari tempat asing dan dari masa lalu yang tidak ditafsirkan ke masa kini, maka kelampauan cerita akan semakin terasa dan terpisah dengan 
kejadian masa kini. Meski demikian orang akan tetap bisa mengenali semangat cerita tersebut.

Historifikasi terdapat pada lakon-lakon Kethoprak yang berpijak pada sejarah dan kehidupan tradisi rakyat. Beberapa naskah Kethoprak di tulis secara pakem (baku, babon) ataupun dalam bentuk carangan (bebas dari susastra lokal), tetapi ketika dipentaskan orang segera saja mengenali bahwa kejadian yang ada di atas panggung merupakan gambaran kejadian nyata dalam keseharian masa itu. Akan tetapi orang tidak akan menjadi larut secara emosional dan mengalami katarsis, karena kejadian di atas panggung sudah dibungkus dengan idiom-idiom masa lampau atau berbeda secara budaya.

Alinasi (Alienation) adalah usaha untuk menggambarkan sebuah peristiwa ke dalam bentuk baru yang bertujuan untuk mencegah penonton menjadi katarsis (Encyclopedia of World Drama, 1972: 250). Kernodle menganggap kata yang tepat semestinya adalah Objectivity, karena memang Brecht menginginkan penonton berada dalam posisi selayaknya seorang siswa yang mendengarkan ceramah dalam kelas (Kernoddle, 1967: 50). Sedangkan Brecht menyatakan bahwa yang di maksud sebagai alinasi adalah proses dimana aktor semata-mata hanya dituntut untuk menunjukkan tokoh yang diperankannya, atau istilah lain aktor tidak semata-mata mengalami apa yang dirasakan tokoh sesuai yang diperankannya.

Alinasi pada Kethoprak, statement dalam lakon yang diperankan tokoh bukan berarti seorang aktor hanya dingin bagaikan robot, tetapi yang harus dijaga adalah bahwa seorang aktor tidak boleh larut oleh perasaan tokoh yang dibawakannya. Hal ini dimaksudkan agar penonton tidak hanyut dalam perasaan tokoh di atas panggung dan kehilangan daya kritisnya (Sihombing, 1980: 267). Sehingga, harapan Brecht bahwa teater yang baik adalah teater yang mampu membawa penonton untuk berfikir kritis dan kemudian melakukan perubahan. Lakon "Ario Penangsang", hampir semua masyarakat penyangganya mengetahui bagaimana heroiknya tokoh utama tersebut dalam membela nasibnya. Tokoh "Arya Penangsang" hanya akan memberikan katarsis pasif hanyut oleh perasaan masing-masing bagi penonton, tetapi tidak harus menawarkan perubahan apapun.

Seorang aktor dapat menampilkan karakter dan implikasi sosial jauh lebih baik apabila dia bisa menjaga jarak antara dirinya dengan tokoh yang diperankannya, dalam hal ini Brecht sangat terkesan dengan pola akting China yang mampu menampilkan sebuah tokoh dengan penuh objektivitas. Objektivitas yang dimaksud terlihat pada pola pengadegan Kethoprak dengan cara menyebutkan nama dalam berperan, bahkan memperkenalkan diri kepada penonton secara ekplisit peran apa yang akan dibawakan. Cara tersebut menyebabkan seorang paraga (aktor) Kethoprak sadar bahwa dia sedang berperan sehingga ada batas yang jelas antara emosi tokoh dan emosi aktor. Dia harus menyadari apa yang dia lakukan adalah untuk kepentingan penonton dan bukannya untuk kepuasan diri sendiri, hal ini juga yang mengharuskan seorang aktor bisa mengontrol dirinya sendiri.

Epik seperti telah dibahas terdahulu, diambil dari kata Epos atau cerita kepahlawanan. Pertunjukan Brecht dipengaruhi teater Timur Opera China sehingga menampilkan epos dihadapan penonton, tidak hanya cerita yang 
dikandung, tetapi yang lebih penting adalah teknis pemanggungannya. Teknis yang menarik perhatiannya, pertama adalah pergantian set yang terjadi pada saat pementasan berlangsung, meski di teater Timur hal tersebut bukanlah sesuatu yang aneh. Teater Tradisional Jepang juga melakukan hal yang sama, selama pergantian dilakukan oleh crew yang berpakaian serba hitam, penonton tidak akan merasa terganggu. Kethoprak di Jawa yang mengharuskan seorang dengan peran raja atau adipati saat muncul ke dalam panggung sambil membawa sendiri kursi kebesarannya. Kedua adalah desain set yang mobile, perpindahan set saat pementasan mengharuskan set dirancang secara kompak atau bahkan minimalis. Karenanya set pertunjukan teater epik kadangkala menggunakan slide projector untuk memproyeksikan kesan yang diinginkan di atas panggung. Set keraton pada Kethoprak hanya ditandai dengan payung atau tombak diatas pangung kain hitam. Ketiga adalah pada struktur naskahnya, pada naskah The Caucasian Chalk Circle Brecht menampilkan seorang tokoh pencerita atau narator. Tokoh ini seolah-olah terlepas dari struktur cerita secara keseluruhan karena memang tidak memiliki tendensi aspek fisologis, psikologis ataupun sosiologis dalam pementasannya salah satu contoh adalah guyonan dagelan pada salah satu adegan Kethoprak, meski demikian tokoh tersebut sangat penting sebagai penjalin hubungan antar adegan.

\section{Alinasi pada struktur naskah Kethoprak}

Brecht mengemukakan pendapatnya tentang alinasi hanya pada tataran teoritis saja, artinya Brecht tidak memiliki metode latihan yang bersifat praktis bagi aktornya. Pendapatnya tentang alinasi terangkum dalam naskah yang ditulisnya, oleh karena itu memahami alinasi berarti memahami naskah karyanya. Memahami naskah artinya membicarakan strukturnya.

\section{Tema}

Tema adalah inti persoalan yang dijabarkan melalui alur, penokohan, latar, suasana dan gaya (Eneste, 1991:65). Sedangkan Simatupang berpendapat tema adalah ide yang mendasari drama (Landung Simatupang, 1987: 15). Jadi tema adalah sebuah ide dasar yang dipergunakan oleh pengarang untuk menuliskan karyanya. Banyak tema dijabarkan secara implisit dari awal hingga akhir cerita. Tema tersebut dapat terlihat di dalam drama melalui alur ataupun dialog (Kernoddle, 1967:354-355). Karya-karya Brecht secara umum mengangkat perjuangan kelompok kecil masyarakat melawan kekuasaan atau hipokrisi. Tema tersebut juga banyak terdapat pada lakon Kethoprak biasanya diangkat dari teksteks sejarah legendaries, namun wujudnya berubah-ubah, bergantung pada pengelola dan pembuat pertunjukannya, maka Kethoprak banyak mengalami alinasi karena sudah melalui historifikasi.

\section{Alur}

Alur adalah rangkaian peristiwa yang direka dan dijalani dengan seksama, yang menggerakkan jalan cerita melalui perumitan (penggawatan atau komplikasi), masuk klimaks dan selesai. Alur adalah jalinan peristiwa di dalam karya sastra untuk mencapai efek tertentu. Pautannya dapat diwujudkan oleh hubungan temporal (waktu) dan kausal (sebab akibat). Sebuah naskah bersumber dari intensitas alur (Kernoddle, 1967: 345). Pola pengadegan memiliki kemiripan seperti film atau montage dimana secara keseluruhan, lakon hanya merupakan 
tempelan kejadian yang berlainan. Teknik montage ini juga menjadi salah satu ciri teater epik Brecht. Alur dalam naskah lakon-lakon Kethoprak pada dasarnya banyak yang tidak berkembang secara runtut dan linear, tetapi terbentuk dari penggabungan kejadian-kejadian yang saling mempengaruhi, kejadian-kejadian tersebut ditampilkan dalam bentuk adegan. Pada tiap adegan terdapat keteganganketegangan atau klimaks minor. Intensitas klimaks pada tiap adegan tidak sama dan linear. Rangkaian klimaks minor tersebut mengantarkan cerita Kethoprak menuju klimaks mayor. Montage dan alur yang tidak linear menimbulkan alinasi karena penonton akan selalu sadar bahwa apa yang ada dihadapan mereka hanyalah merupakan tontonan semata.

\section{Penokohan}

Tokoh adalah sesuatu yang menggambarkan bagaimana sesuatu terjadi dalam naskah (Kernoddle, 1967: 349). Adapun cara yang paling sederhana dalam penokohan adalah pemberian nama. Tokoh juga berfungsi sebagai penyampai ide pengarang yang berfungsi sebagai penggerak cerita. Meski demikian, tokoh-tokoh dalam naskah Brecht tidak memiliki sifat tiga dimensional. Hal ini merupakan konsekuensi logis dari tokoh-tokohnya yang tidak mempunyai motivasi individual sama sekali (Kernoddle, 1967: 171). Ini menyebabkan tokoh-tokoh tersebut memiliki kecenderungan split personality atau kepribadian ganda (Chairul Anwar, 1996: 40). Dengan kecenderungan tersebut, aktor tidak akan terjebak pada identifikasi diri dengan peran karena sewaktu-waktu harus berubah menjadi tokoh lain. Penokohan semacam ini sangat mendukung terjadinya alinasi, seperti halnya dalam Kethoprak, tokoh-tokoh diatas panggung bukanlah tokoh yang bisa diidentikan dengan realitas kehidupan nyata, sehingga penonton tidak akan mengidentifikasikan dirinya dengan tokoh di atas panggung, yang muncul adalah usaha penonton untuk memahami kejadian di atas panggung secara intelektual.

\section{Alinasi pada tekstur naskah Kethoprak}

Kernodle menyatakan bahwa tekstur sebuah drama adalah segala sesuatu yang dapat didengar telinga, dilihat mata, dan dirasakan sebagai mood oleh penonton (Kernodle, 1967:345). Komponen tekstur tersebut terdiri dari dialog, spectacle dan suasana. Tekstur drama baru muncul ketika sebuah naskah dipentaskan, berbeda dengan cerpen atau novel aspek tekstur tersebut tidak muncul. Meskipun tekstur drama baru muncul ketika dipanggungkan, kemungkinan-kemungkinan yang ada sudah bisa dilihat dari struktur naskah. Struktur naskah telah memberikan petunjuk bagi terciptanya struktur drama, dengan kata lain tekstur drama merupakan pengejawantahan dari struktur. Berdasar pada pernyataan tersebut, apabila di dalam pembahasan mengenai struktur naskah-naskah karya Brecht dibuktikan adanya alinasi, maka dalam tekstur Kehoprak, alinasi juga bisa dibuktikan keberadaanya di bawah ini:

\section{Dialog}

Dialog menjadi alat penyampai gagasan, pikiran pengarang, diucapkan oleh tokoh, sehingga ada hubungan sangat erat antara penokohan dan dialog. Disadari pula bahwa ide-ide pengarang disampaikan oleh tokoh melalui dialog yang diucapkannya. Hubungan timbal balik tersebut, Akhudiat (1980:38-68) membagi fungsi dialog menjadi menjadi enam, yaitu: menyampaikan informasi, 
mengungkapkan perwatakan tokoh, menjuruskan ke elemen plot yang penting, mengungkapkan tema dan ide drama, membantu meletakkan nada dasar dan kemungkinan-kemungkinan, memantapkan tempo dan ritme. Konteks tekstur dalam Kethoprak, dialog yang dimaksud tidak hanya berupa tulisan yang ada dalam lembaran-lembaran naskah, tetapi lebih pada saat dialog tersebut diucapkan, meski demikian dialog dalam naskah memperlihatkan fungsi adanya Alinasi.

\section{Mood}

Mood dalam bahasa Indonesia diterjemahkan sebagai suasana. Mood dalam teater tergantung dari perpaduan banyak unsur, termasuk bahasa, spectacle, dan irama. Irama dirasakan langsung oleh penonton ketika melihat pemain bergerak, berdialog dan juga pergantian pencahayaan (Kernodle, 1967:357). Irama permainan menentukan terciptanya mood yang mengakibatkan penonton berada pada keadaan tertentu. Kethoprak mempunyai irama permainan, hal ini sangat dipengaruhi oleh struktur naskah maupun teknik pemanggungan.

Alur memegang peranan penting bagi tercapainya suatu bentuk irama permainan. Alur berbentuk montage, ditambah dengan adanya narator memberi nilai tersendiri terhadap mood. Dalam pertunjukan, teknik montage merupakan jalinan dari cerita yang disatukan sehingga menimbulkan suasana. Pada lakonlakon Kethoprak setiap adegan hampir memiliki montage yang menegangkan dan sulit ditebak alurnya, hal inilah yang memunculkan mood bagi penonton.

\section{Spectacle}

Spectacle bisa dijelaskan sebagai segala sesuatu yang menarik untuk dinikmati terutama dengan melihatnya (Kernodle, 1967:356). Penonton akan menyukai perhiasan-perhiasan gemerlap seorang ratu ataupun bangunanbangunan megah daripada seorang gembel di muka gubugnya. Kecenderungan drama-drama klasik untuk menampilkan spectacle lewat kemegahan dan kemewahan tidak didapati pada naskah-naskah Brect. Spectacle ditampilkan Brecht lewat simbolisasi minimal dan kepraktisan setting atau propertinya. Hal tersebut tampak pada pertunjukan Kethoprak perwujudan spectacle yaitu pada setting yang mobile. Pemakaian busana para raja yang abyor mompyor (gemerlap) merupakan simbol tertentu, berbeda dengan kostum para biyung emban. Brecht menyadarkan penonton terhadap kenyataan teater yang harus dinikmati sebagai tontonan menyebabkan penontonnya berusaha mencari jawaban terhadap masalah yang ada (Sihombing, 1980: 266).

\section{SIMPULAN}

Historifikasi adalah usaha Brecht untuk menempatkan aktor seolah-olah memainkan sebuah adegan sejarah. Alinasi adalah usaha untuk menggambarkan sebuah peristiwa ke dalam bentuk baru yang bertujuan untuk mencegah penonton menjadi katarsis, sedangkan Epik adalah diambil dari kata Epos atau cerita kepahlawanan. Ketiga hal tersebut, alinasi menjadi unsur paling penting dibahas dalam konteks pembicaraan tentang teater Epik, untuk mengetahui adanya alinasi adalah digunakan cara menganalisis struktur naskahnya. Historifikasi-Alinasi- 
Epik juga terdapat dalam pementasan seni drama tradisi Kethoprak, selain pada struktur naskah, alinasi juga terdapat pada struktur naskah yang berupa dialog, mood dan spectacle lakon-lakon Kethoprak. Kejernihan penonton dalam melakukan penilaian terhadap lakon-lakon Kethoprak diyakini Brecht mampu menjadi penggerak bagi tindakan keseharian penonton untuk bersikap kritis.

\section{KEPUSTAKAAN}

Akhudiat, 1980. "Dialog Dalam Naskah Panggung" (makalah diskusi) dalam Serba-Serbi Penyelengaraan Ceramah \& Diskusi Penulisan Naskah Drama Televisi di TVRI Stasiun Surabaya, Surabaya: Bina Ilmu Offset.

Anwar, Chairul. 1996, Laporan Penelitian, Realisme Sosial dan Teater Epik, Yogyakarta: LPM ISI Yogyakarta.

Endraswara, Sewardi. 2011. Metode Pembelajaran Drama, Apresiasi, Ekpresi dan Pengkajian. Yogyakarta; CAPS

Eneste, Pamusuk. 1991, Novel dan Film, Ende: Nusa Indah.

Kernoddle,George R. 1967, Invitation to the Theatre, New York/Chicago/San Francisco/Atlanta: Harcourt, Brace \& World, Inc. . 1978, Portia Kernoddle, Invitation to the Theatre, Brief second Edition New York/ San Diego/ Chicago/ San Francisco/ Atlanta: Harcourt, Brace \& World, Inc.

Sihombing, Wahyu. Slamet Sukirnanto, Ikranagara, ed., 1980, Pertemuan Teater 80. Jakarta: Dewan Kesenian Jakarta

Simatupang, Rusyanto Landung L. 1987, Beberapa Hal Mengenai Penulisan Lakon, Yogyakarta: Citra Yogya.

Soemardjo, Jakob.1986, Ikhtisar Sejarah Teater Barat Penerbit Angkasa: Bandung.

Willet, John. ed,1974. Brecht on Theatre, The Development of An Aesthetic. London: Methuen. 
